\title{
Comparative Analysis of Ceramic Product Manufactured from Traditional Raw Materials and Local Raw Materials in Bangladesh
}

\author{
Abdullah Al Mahmood ${ }^{*}$, Shamimur Rahman, Omar Faruque, Tanmoy Kishor \\ Department of Glass \& Ceramic Engineering, Rajshahi University of Engineering \& Technology, \\ Rajshahi-6204, BANGLADESH \\ Corresponding Contact: \\ Email: abdullah2038@gmail.com
}

\begin{abstract}
Ceramic industries in Bangladesh are using raw materials imported from abroad. For this reason, manufacturing costs of the ceramic products are quite high. Now a day, the demand of the ceramic products in Bangladesh is very high. To reduce the cost of these ceramic products, different types of local clays can be used as raw materials with quartz and feldspar to manufacture ceramic ware, tile, and sanitary ware. In this research, locally available clay of nine different areas had been used to prepare the sample. Their physical and mechanical properties were tested and studied to evaluate the quality of the products. Khagrachari (canal) and Padma (north) clay have shown better physical and mechanical properties. This clay is suitable for the production of ceramic ware and Khagrachari (Hill) and Padma (South) clay for quality tiles. The compositions of locally available clays were determined using X-Ray Fluorescence (XRF). XRF analysis showed the presence of excess $\mathrm{SiO}_{2}$ content in the form of Silicate, $\mathrm{Fe}_{2} \mathrm{O}_{3}$, and $\mathrm{TiO}_{2}$ but the amount of $\mathrm{Al}_{2} \mathrm{O}_{3}$ in most of the compositions was also not up to the minimum level. Observing the physical and mechanical properties, it is found that the local clay materials are suitable to use in ceramic industries by replacing the imported/traditional clay to reduce cost and make a perfect use of our natural resources.
\end{abstract}

Key words

Clay, porosity, compressive strength, ceramic products

\section{INTRODUCTION}

The ceramics is a class of inorganic, nonmetallic solids that are subjected to high temperature in the manufacture and use. The most common ceramics are composed of oxides, carbides, and nitrides. Silicides, borides, phosphides, tellurides, and selenides also are used to produce ceramics. Ceramic processing involves high temperatures, and the resulting materials are 
heat resistant or refractory (www3.epa.gov/ttnchie1/ap42/ch11/final/c11s07.pdf; Kirk 1992; 1987 Census of Manufactures, 1990; Ullman's Encyclopedia of Industrial Chemistry, $5^{\text {th }}$ Ed). The main ingredient of ceramic is different types of clay. Clay is a fine-grained natural rock or soil material that combines one or more clay minerals with traces of metal oxides and organic matter. Clays are plastic due to their water content and become hard, brittle and non-plastic upon drying or firing (Guggenheim \& Martin, 1995). Geologic clay deposits are mostly composed of phyllosilicate minerals containing variable amounts of water trapped in the mineral structure (Science Learning Hub).

Geological surveys indicated that Bangladesh has deposits of both residual and sedimentary types of clays. Some places across the country is better for the sources of various types of ceramic raw materials. Notable locations are Bijoypur in Mymensingh, Barapukuria, and Maddhyapara in Dinajpur, etc. The clays that are available in these sources are mainly China Clay, White Clay, Red Clay, Black Clay, Brick Clay, etc. (Adnan et al, 2011). In this paper, other than these clays, nine different clays from different sites of Bangladesh are characterized. Those locations are Khagrachari (canal), Khagrachari (hill), Khagrachari (plain land), Padma (south), Padma (north), Padma (river), Isamoti (ataikula), Isamoti (bera), Isamoti (pabna). The aim of the research is the study of chemical composition, physical properties and mechanical properties of the ceramic product and their firing behavior.

\section{Materials AND Methods}

\section{Beneficiation of Local Clay}

When using the local clay, clay refining is an important and first step of methodology. 2 kilograms of clay lumps were crushed into small size particles by crusher machine. Then crushed particles were soaked in water for about a week. In the soaked clay, heavier and fine particles were formed in a suspension with some impurities. The clay suspension was washed through a sieve ASTM-200. Then larger size particles were separated and fine particles were mixed with the water in the final slurry. Also a magnetic separator was used to separate the magnetic particles in the mixture. The final mixture was dried in the sun for initial drying. Finally, it was dried in a dryer for 24 hours to get fine clay particles.

\section{Formulation and preparation of different batches}

Table 1 shows the batch composition of different clay. In the mixture feldspar was used $30 \%$, quartz $30 \%$, and different types of clay was used $40 \%$. Small amount of molasses was used as binding agent.

Table 1: Batch composition

\begin{tabular}{|l|c|c|c|c|}
\hline \multicolumn{1}{|c|}{ Batch of different clay } & $\begin{array}{c}\text { Feldspar } \\
(\mathrm{wt} \%)\end{array}$ & $\begin{array}{c}\text { Quartz } \\
(\mathrm{wt} \%)\end{array}$ & $\begin{array}{c}\text { Local clay } \\
(\mathrm{wt} \%)\end{array}$ & $\begin{array}{c}\text { Water } \\
(\mathrm{wt} \% \text { of batch) }\end{array}$ \\
\hline Khagrachari (Canal) & 30 & 30 & 40 & $60 \%$ \\
\hline Khagrachari (Hill) & 30 & 30 & 40 & $60 \%$ \\
\hline Khagrachari (Plain land) & 30 & 30 & 40 & $60 \%$ \\
\hline Padma (South) & 30 & 30 & 40 & $60 \%$ \\
\hline Padma (North) & 30 & 30 & 40 & $60 \%$ \\
\hline Padma (River) & 30 & 30 & 40 & $60 \%$ \\
\hline Isamoti (Ataikula) & 30 & 30 & 40 & $60 \%$ \\
\hline Isamoti (Bera) & 30 & 30 & 40 & $60 \%$ \\
\hline Isamoti (Pabna) & 30 & 30 & 40 & $60 \%$ \\
\hline
\end{tabular}




\section{Experimental procedure}

Each composition was subjected to ball milling for 20 hours to get fine particles. Then it was dried at room temperature. The particles size is an important criterion for the quality of the product. The mixture was grinded to fine powder to achieve particles size less than 200 meshes. At this stage the powder was mixed with small amount of molasses. The molasses is the waste product of sugar mills available in local area. The mixture was then wrapped in polythene to prevent moisture loss or absorb. After a week the mixture was ready to prepare the samples. Several square shaped samples $(50 \mathrm{~mm} \times 50 \mathrm{~mm} \times 10 \mathrm{~mm})$ were prepared at a pressure 250 bars using a hydraulic press. The pressure used to achieve compact shaped samples. The green samples were first dried in open air for 2 hours. Then it was dried in an oven at $110{ }^{\circ} \mathrm{C}$. Finally, it was fired at three different temperatures $\left(1050{ }^{\circ} \mathrm{C}, 1100{ }^{\circ} \mathrm{C}\right.$, and $1150{ }^{\circ} \mathrm{C}$ ) to see the effect of sintering temperature. The soaking period was 90 minutes. A flow diagram of the above mentioned preparation procedure is shown in Figure 1.

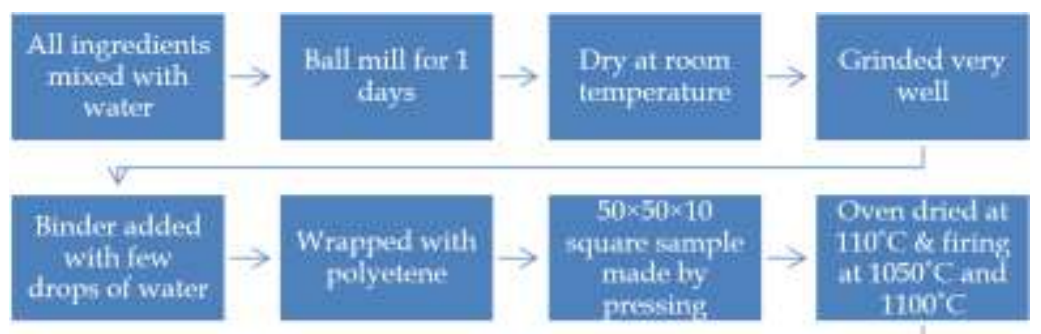

Finished firing

product

Fig 1: Flow diagram of tile samples preparation

\section{Results AND Discussions}

Fig 2-5 represents the XRF patterns of several clays used in the analysis. Table 2 summarizes the elements found in the analysis of different clays. In the analysis, $\mathrm{SiO}_{2}$ found the maximum percentage in all the samples. Aluminium oxide $\left(\mathrm{Al}_{2} \mathrm{O}_{3}\right)$ was the second highest amount for the samples where other elements like $\mathrm{TiO}_{2}$, iron oxide, and other components found in the analysis in small percentage.

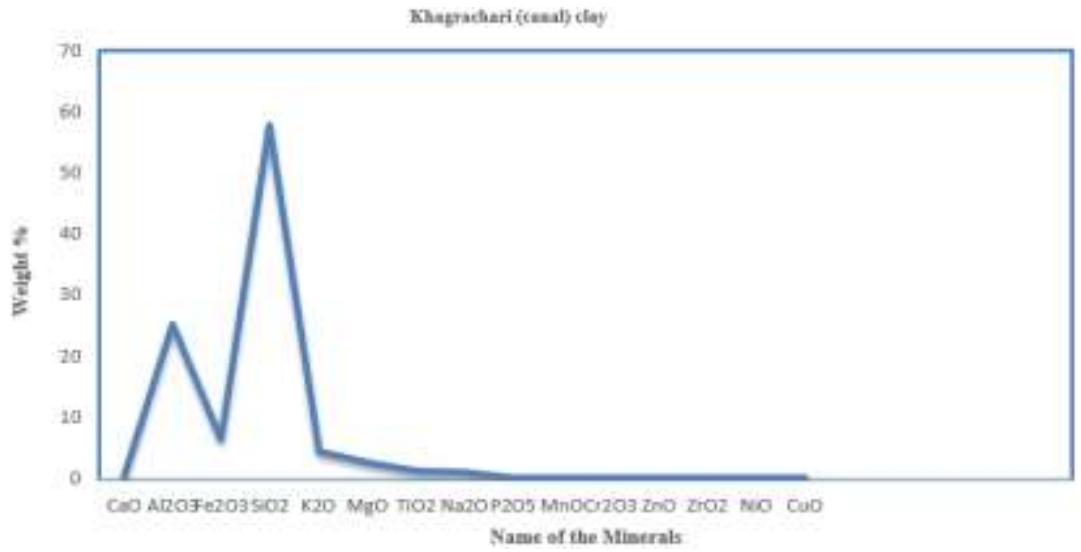

Fig 2: XRF analysis of Khagrachari (canal) clay 


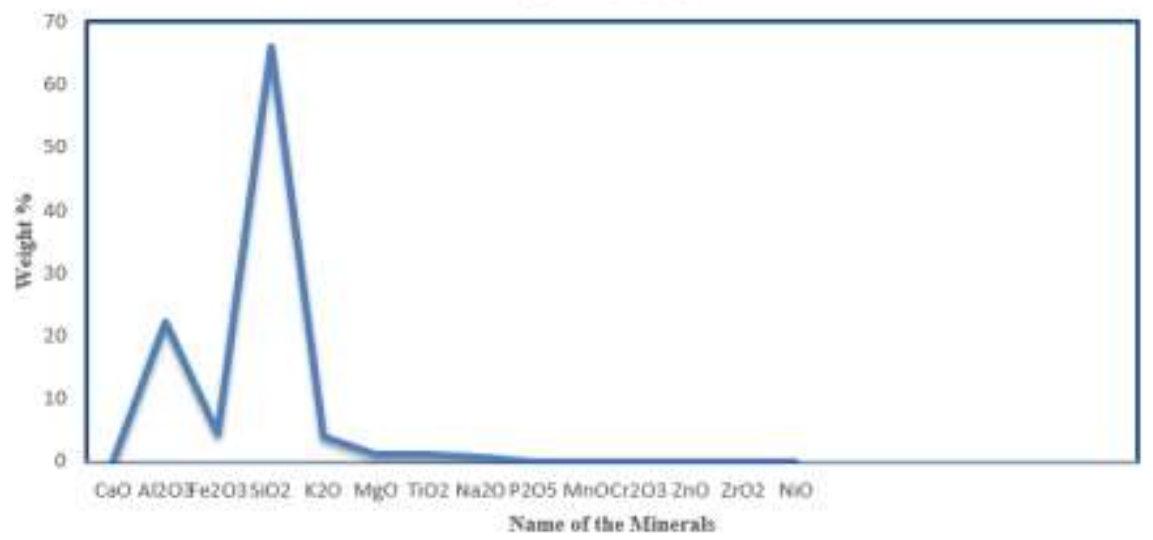

Fig 3: XRF analysis of Khagrachari (hill) clay

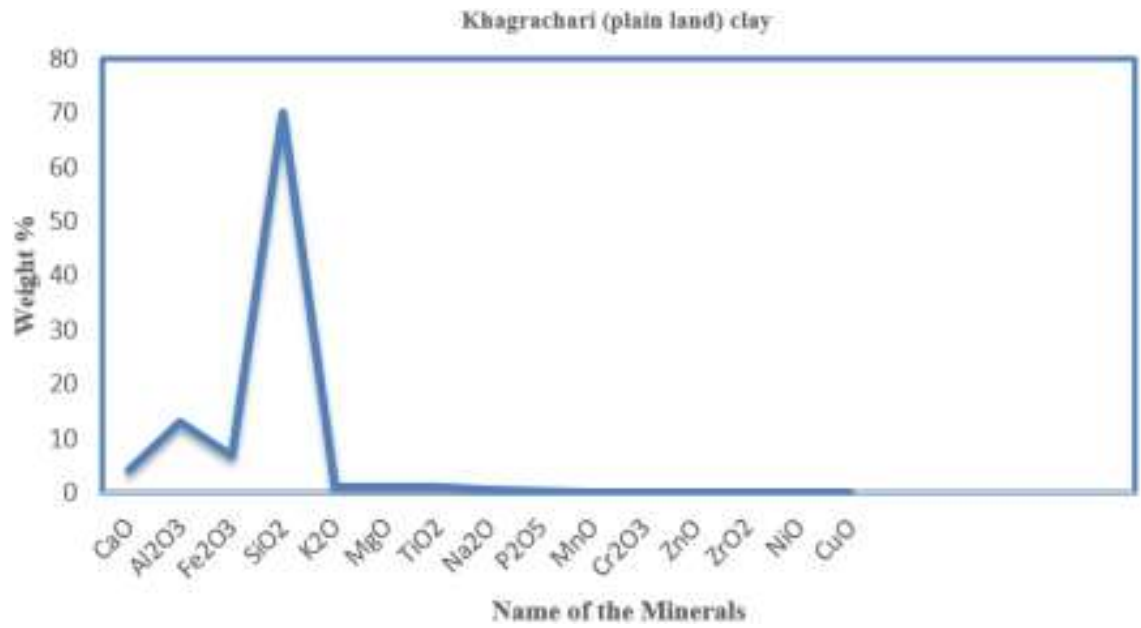

Fig 4: XRF analysis of Khagrachari (plain land) clay

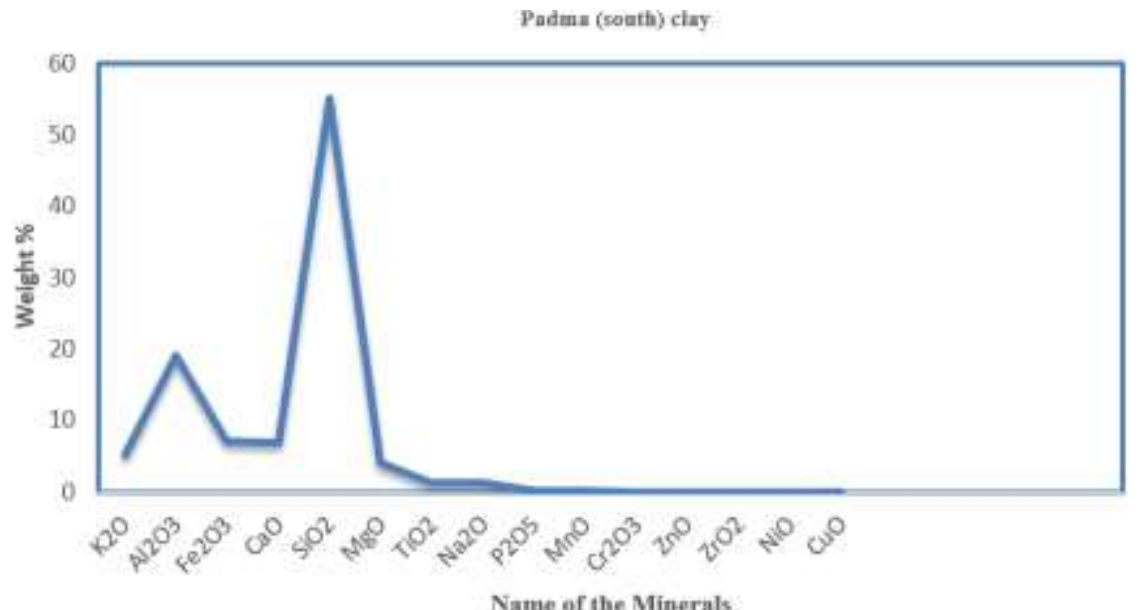

Fig 5: XRF analysis of Padma (south) clay 
Table 2: XRF analysis of locally available clay and imported clay

\begin{tabular}{|c|c|c|c|c|c|c|c|c|c|c|c|}
\hline $\begin{array}{l}\text { : } \\
\stackrel{0}{0} \\
0 \\
\stackrel{0}{0} \\
0 \\
0\end{array}$ & 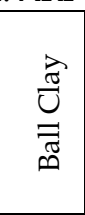 & 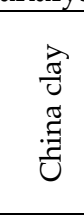 & 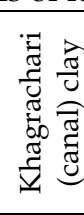 & 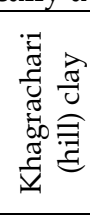 & 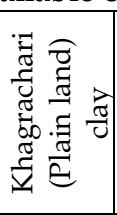 & 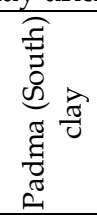 & 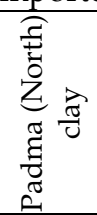 & 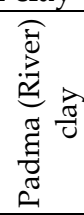 & 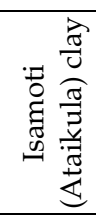 & 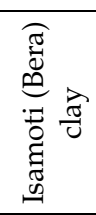 & 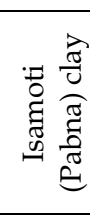 \\
\hline $\mathrm{SiO}_{2}$ & 44.63 & 50.18 & 57.91 & 65.96 & 69.91 & 55.00 & 52.64 & 62.01 & 57.60 & 62.61 & 59.65 \\
\hline $\mathrm{Al}_{2} \mathrm{O}_{3}$ & 36.93 & 33.34 & 25.13 & 22.28 & 13.13 & 19.11 & 17.90 & 12.11 & 15.55 & 11.92 & 10.90 \\
\hline $\mathrm{Fe}_{2} \mathrm{O}_{3}$ & 0.96 & 1.88 & 6.44 & 4.40 & 6.92 & 6.99 & 7.96 & 7.01 & 8.61 & 8.62 & 8.42 \\
\hline $\mathrm{TiO}_{2}$ & 3.57 & 0.01 & 1.33 & 1.14 & 1.16 & 1.18 & 1.27 & 1.39 & 1.26 & 1.15 & 1.20 \\
\hline Others & 13.91 & 14.59 & 9.17 & 6.19 & 8.88 & 17.69 & 20.20 & 17.48 & 16.95 & 15.70 & 19.83 \\
\hline
\end{tabular}

\section{Physical and mechanical properties}

Physical and mechanical characteristics were considered to examine the quality of the products. Tiles of nine different clays were prepared, and their physical properties such as porosity, moisture content, plasticity, density, firing shrinkage, water absorption, hardness, compressive strength were tested to evaluate the quality of the products.

\section{Porosity}

Porosity depends on temperature, as the temperature increases the amount of porosity of any sample decreases. Fig.6-8 represent the porosity of all samples at three different temperatures. The porosity behavior changes with sintering temperature. The minimum porosity is good for the quality of the products. When porosity is minimum the density of the products will be maximum and hence the strength will be high. At $1100^{\circ} \mathrm{CKhagrachari}$ (Canal), Khagrachari (Plainn land), Padma (river) shows porosity about 16.35\%, 21.38\%, $20.44 \%$ respectively. But at $1150^{\circ} \mathrm{C}$ the porosity percentage decreases.

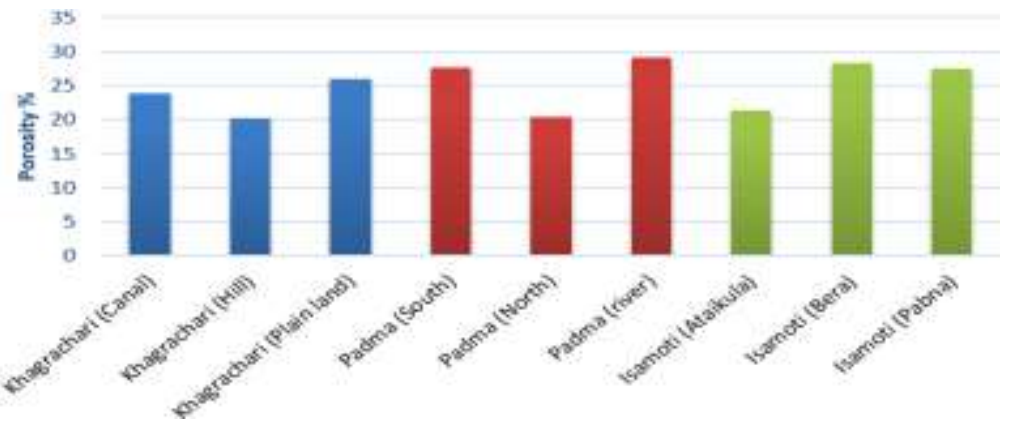

Fig 6: Porosity of the samples fired at $1050^{\circ} \mathrm{C}$

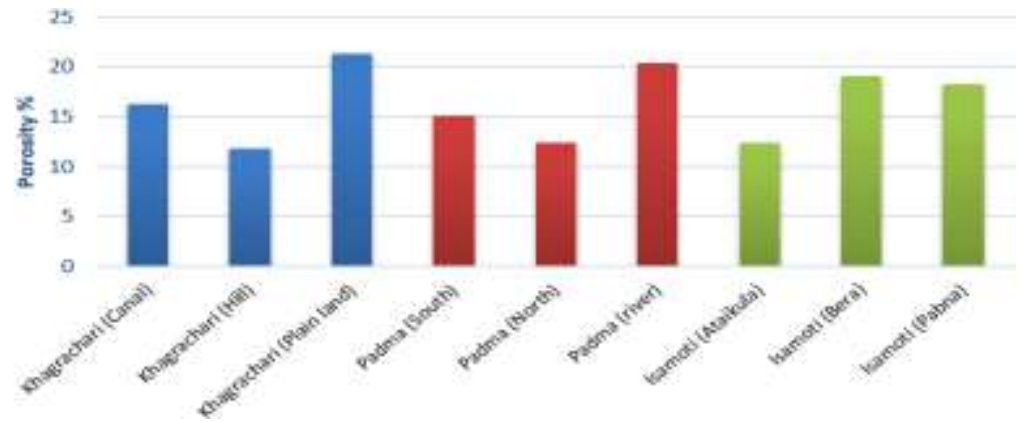

Fig 7: Porosity of the samples fired at $1100^{\circ} \mathrm{C}$ 


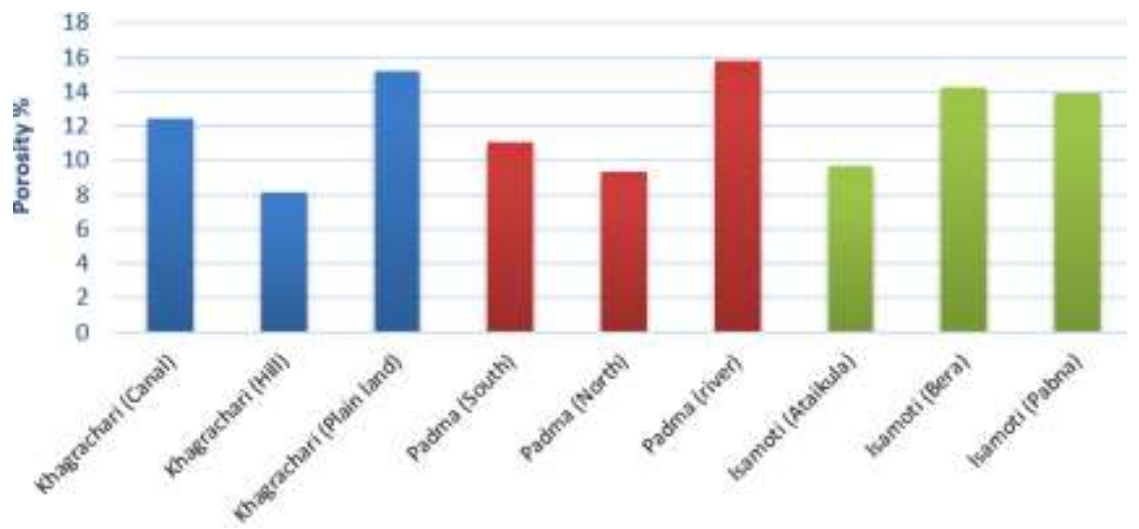

Fig 8: Porosity of the samples fired at $1150^{\circ} \mathrm{C}$

\section{Compressive strength}

The compressive strength values of all the samples in this work are shown in Fig.9-11. These values found by measuring different parameters in the equation. To measure the compressive strength at first, the samples are prepared according to the ASTM C773 88 (2016) $(50 \times 14 \times 8 \mathrm{~mm})$ and placed on the machine. Then a load is applied to the sample for some time. The final load was noted down where the fracture of the sample occurs.

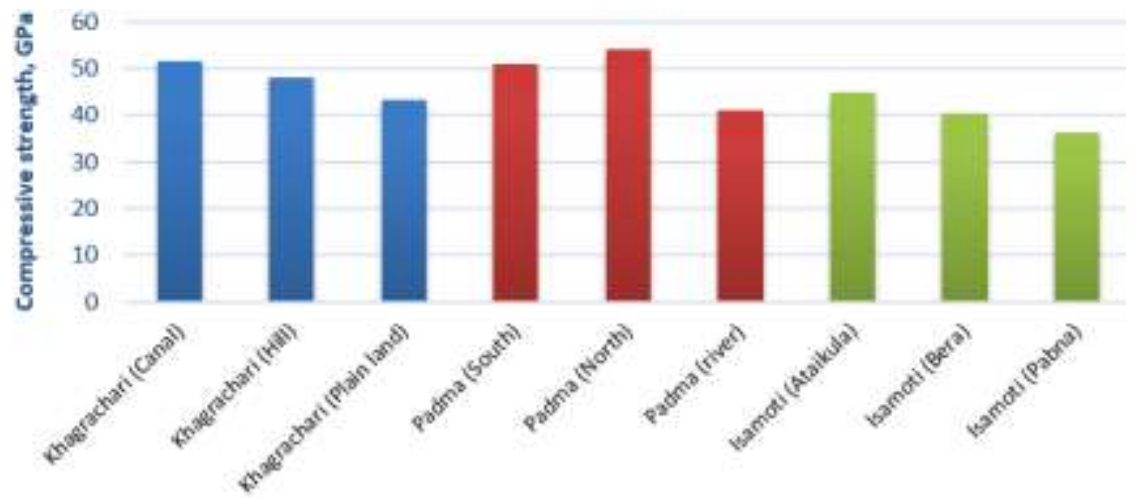

Fig 9: Compressive strength at $1100^{\circ} \mathrm{C}$

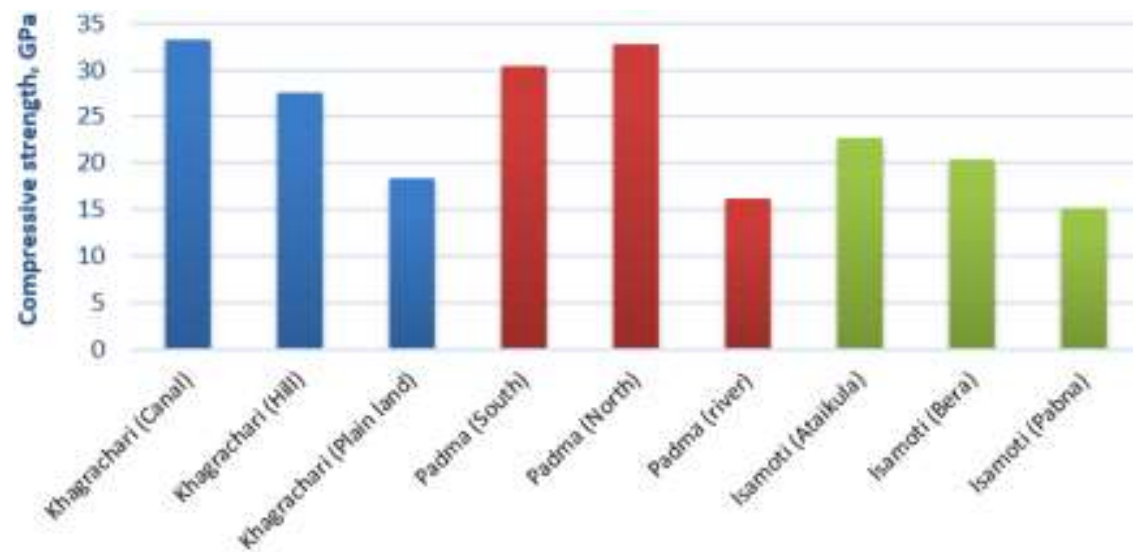

Fig 10: Compressive strength at $1050^{\circ} \mathrm{C}$ 


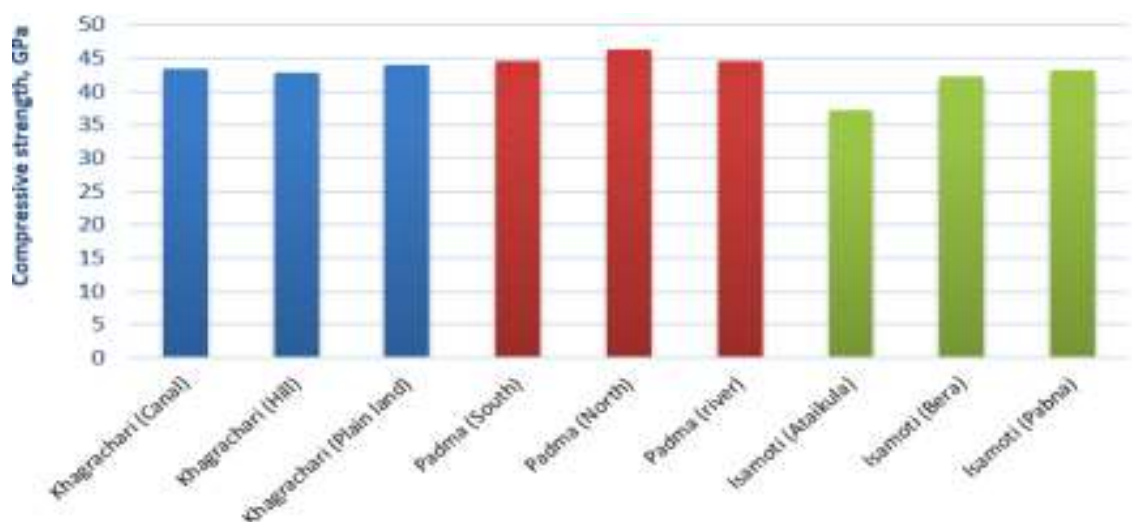

Fig 11: Compressive strength at $1150^{\circ} \mathrm{C}$

The compressive strength of all the samples increase with the increase of temperature which is representing in figure 9, 10 and, 11 . At $1100^{\circ} \mathrm{C}$ and $1150^{\circ} \mathrm{C}$ Khagrachari (Canal), Padma (South) and Padma (river) show very high compressive strength.

Table 3: Physical and mechanical properties of prepared samples and comparison with

\begin{tabular}{|c|c|c|c|c|c|c|c|c|c|c|}
\hline 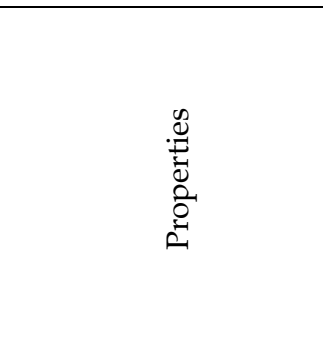 & 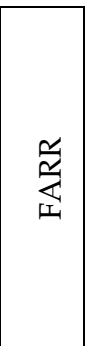 & 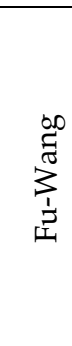 & 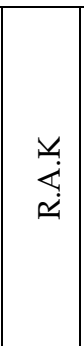 & 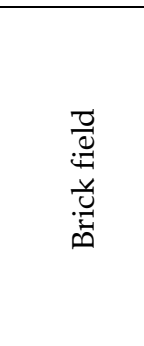 & 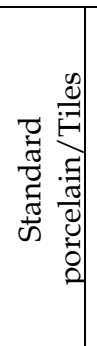 & 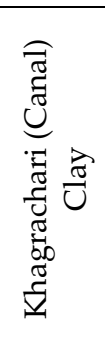 & 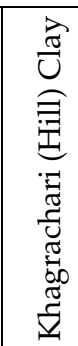 & 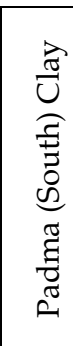 & 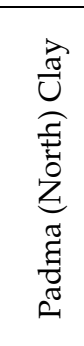 & 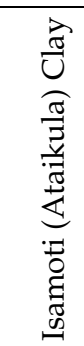 \\
\hline Density & .76 & 1.54 & 1.68 & $1.03-1.5$ & - & 1.83 & 1.81 & 1.76 & 1.85 & 1.69 \\
\hline Water absorp & $8-10$ & 16.7 & 12.10 & $20-22$ & - & 14.41 & 11.22 & 12.69 & 9.20 & 10.61 \\
\hline Porosity & $10-12$ & 27.0 & 20.68 & 38.16 & 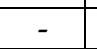 & 16.35 & 11.85 & 15.18 & 12.41 & 12.40 \\
\hline Hardness & - & - & - & $1.765-2.55$ & $5-10$ & 4.7 & 3.88 & 6.26 & 6.49 & 5.13 \\
\hline Compressive strength & - & - & - & $1.9-10.8$ & $50-60$ & 51.46 & 48.09 & 50.82 & 54.26 & 44.92 \\
\hline
\end{tabular}

commercial standard (For $1100{ }^{\circ} \mathrm{C}$ )

Table 3 shows the comparison of physical and mechanical properties of the finished products with the properties of commercially available tiles of several ceramic industries (Farr, Fu-Wang and, R.A.K) these values are collected from the respected factories. Table 3 shows the comparison of physical properties such as density, water absorption, porosity, hardness, and compressive strength with the standard values.

\section{CONCLUSION}

The motive of this investigation was to reduce the cost of producing ceramic ware and to ensure the proper utilization of local clay resources. The compositions of locally available clay are determined by using X-Ray Fluorescence (XRF). Due to high percentages of impurity content in local clay, these clays are refined. The samples were made by the traditional method of tiles production using hydraulic press machine. In the experiment nine different types of local clay samples and three different temperatures $\left(1050^{\circ} \mathrm{C}, 1100^{\circ} \mathrm{C}\right.$, and $1150^{\circ} \mathrm{C}$ ) were used. The physical and mechanical properties of the produced tiles at 
$1100^{\circ} \mathrm{C}$ was close to the properties of commercially available tiles. So $1100^{\circ} \mathrm{C}$ is the optimum temperature for these local clays. Then some basic physical and mechanical properties such as firing shrinkage, water absorption, density, bending strength, compressive strength, and hardness had been tested and recommended as bellows:

- Khagrachari (canal) clay - ceramic ware and quality tiles.

- Khagrachari (hill) clay - quality tiles.

- Khagrachari (plain land) clay - low quality tiles and brick field.

- Padma (south) clay - quality tiles.

- Padma (north) clay - ceramics wares and quality tiles.

- Padma (river) clay - pottery and bricks.

- Isamoti (ataikula) clay - bricks and pottery.

- Isamoti (bera) clay - tiles.

- Isamoti (pabna) clay - bricks and pottery.

\section{REFERENCES}

1987 Census of Manufactures, U. S. Department of Commerce, Washington, D.C., May 1990.

Adnan Mousharraf, Md. Sazzad Hossain, Md. Fakhrul Islam. (2011), "Potential of Locally Available Clay as Raw Material for Traditional-Ceramic Manufacturing Industries", Journal of Chemical Engineering, IEB Vol. ChE. 26, No. 1, December 2011. www.banglajol.info/index.php/JCE/article/

Alam, M., \& Quevauviller, P. (2013). A Comparative analysis of Bangladesh Water Management Practice with European Water Framework Directives. Engineering International, 1(2), 48-60.

Alam, M., Willems, P., \& Alam, M. (2014). Comparative Assessment of Urban Flood Risks due to Urbanization and Climate Change in the Turnhout Valley of Belgium. ABC Journal of Advanced Research, 3(1), 15-24.

Alam, M., Willems, P., \& Alam, M. (2014). Comparative Assessment of Urban Flood Risks due to Urbanization and Climate Change in the Turnhout Valley of Belgium. ABC Journal Of Advanced Research, 3(1), 14 - 23.

Guggenheim \& Martin 1995, pp. 255-256, https:/ /en.wikipedia.org/wiki/Clay\#CITEREFGuggenheimMartin1995

Kirk-Othmer. Encyclopedia of Chemical Technology, Fourth Edition, Volume 5, John Wiley \& Sons, New York, 1992

Masum, A., \& Johora, F. (2015). Performance Evaluation of Selected Ceramic Companies of Bangladesh. Asian Business Review, 1(1), 37-48. doi: http:/ /dx.doi.org/10.18034/abr.v1i1.335

Science Learning Hub "What is clay". University of Waikato. Retrieved 10 January 2016.

Ullman's Encyclopedia of Industrial Chemistry, Fifth Edition, Volume A6.

University College London Geology on Campus: Clays. Earth Sciences department. University College London. Retrieved 10 January 2016.

www3.epa.gov/ttnchie1/ap42/ch11/final/c11s07.pdf

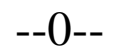

ISSN: 2409-3629

Online Archive Link: https://abc.us.org/ojs/index.php/ei/issue/archive 